\title{
Kuopion läänin perhelisäperheistä ja niiden asunto- ym. oloista
}

Vertaileva tilastollinen selvitys.

Kirjoittanut Armas Nieminen.

JOHDANTO.

Selvityksen tarkoitus ja toimeenpano.

Väestökysymyksen tutkimuksessa on keskeisessä asemassa perheen suuruuden ja elintason välillä vallitsevan riippuvaisuussuhteen valaiseminen. Lisiä tämän kysymyksen selvittämiseen (Ruotsissa suoritetuista täsmällisemmistä tämänlaatuisista tutkimuksista vrt. ed. ss. $34,44-$ 47) tarjoaa suurten perheiden olojen tutkiminen ja vertaaminen vastaavan yhteiskuntaryhmän pieniperheisten tai perheettömien oloihin.

Väestöliitolle on tarjoutunut kaksi mahdollisuutta tällaisiin tutkimuksiin. Ensimmäinen näistä suoritettiin vuonna 1943 helsinkiläisten perheiden keskuudessa, joilla oli oikeus saada erinäisiä lisäelintarvikekortteja ja joihin siis kuului vähintään neljä 19 vuotta nuorempaa kotona asuvaa lasta. Tämän tilastollisen selvityksen tuloks€t on julkaistu Väestöliiton ensimmäisessä vuosikirjassa. ${ }^{1}$

Toinen tilaisuus̀ monilapsisten perheiden olojen tutkimiseen Väestöliitolla oli, kun liiton toimesta kesäkuukausina 1945 
suoritettiin erinäisissä pohjois- ja keski-Savossa sijaitsevissa Kuopion läänin kunnissa, Tu usniemellä, M u u ruvedellä, Nilsiässä ja Vieremällä edellisessä kirjoituksessa selostettu tutkimus maaltapakoilmiöstä ja sen syistä. Kun tätä tutkimusta varten oli palkattava henkilöitä hankkimaan paikkakunnalta tietoja poismuuttaneista, kävi mahdolliseksi antaa heidän samalla tutustua myös sikäläisten suurten perheiden oloihin. Valtaosan suurista perheistä muodostavat perhelisälain mukaista valtion perhelisää nauttivat perheet (ks. ss. 152-153), ja juuri näihin selvitys päätettiinkin kohdistaa, kun kortisto niistä oli nähtävissä kuntien huoltolautakunnissa. Tutustuttuaan tutkittavalla paikkakunnallaan tähän kortistoon kukin tietojenkerääjä kävi siinä mainittujen perheiden luona ottamassa selkoa monista perheen jäseniä, asuntoa ja toimeentuloa koskevista seikoista. Selvittely kohdistui erityisesti asunto-oloihin, koska näistä jo aikaisemmin on toimitettu seikkaperäisiä tutkimuksia ${ }^{2}$, jotka soveltuivat tämän selvityksen vertailuaineistoksi.

\section{Tutkimuskuntien edustavuus.}

Kun tutkimuskuntien lukumäärä käsitti vain $7,5 \%$, yhteinen pinta-ala (ilman vesiä vuoden 1945 alussa) $6,9 \%$ ja yhteenlaskettu väkiluku (henkikirjoitetun väestön määrä vuoden 1945 àlussa, myös siirtoväki huomioon otettuna) 7,1\% Kuopion läänin koko maaseudun vastaavista luvuista ${ }^{3}$, herää kysymys, miten suuressa määrässä selvityksen tulosten voidaan katsoa edustavan läänin koko maaseudun perhelisäperheitä. Tämä seikka riippuu siitä, missä määrin olot tutkimuskunnissa ovat samankaltaisia kuin läänin maaseudulla yleensä. Tätä kysymystä valaisevat osaltaan seuraavassa asetelmassa esitetyt laskelmat ${ }^{4}$, jotka antavat viitteitä väestön rakenteesta sekä taloudellisista ja sosiaalisista oloista toisaalta tutkimuskunnissa ja toisaalta läänin koko maaseudulla. Yhdistelmään on syntyneitä, kuolleita ja solmittuja avioliittoja koskevat tiedot otettu sotien $1939-45$ 
edelliseltä ajalta, koska miesten sodassa olo on näissä suhtẹissa aiheuttanut satunnaisia epätasaisuuksia eri paikkakuntien kesken.

$\begin{array}{cc}\begin{array}{c}\text { Tutkimus- } \\ \text { kunnat }\end{array} & \begin{array}{c}\text { Läänin koko } \\ \text { maaseutu }\end{array}\end{array}$

Läsnäolevan väestön määrä maakmª̈ kohden

31. 12. 1940 ..........................

Siirtoväkeen kuuluvia \% 1. 1. 1945 henkikirjoitetusta väestöstä .....................

Naispuolisia $0 /{ }_{0}$ koko läsnäolevasta väestöstä 31. 12. 1940 ........................

0-14-vuotiaita \% koko läsnäolevasta väestöstä 31. 12. 1940 ........................

70-vuotiaita ja vanhempia \% koko läsnäolevasta väestöstä 31. 12. $1940 \ldots \ldots \ldots \ldots \ldots$. . . .

Maatalousväestöä \% koko läsnäolevasta väestöstä $31.12 .1940 \ldots \ldots \ldots \ldots \ldots \ldots \ldots \ldots$.

Elävänä syntyneitä keskimäärin vuosittain \%/90 keskiväkiluvusta vv. $1934-1938 \ldots \ldots \ldots$.

Kuolleita keskimäärin vuosittain $\% / 00$ keskiväkiluvusta vv. $1934-1938 \ldots \ldots \ldots \ldots \ldots$.

$10,2=9,4$

$8,1-7,5$

48,5

48,9

31,1

31,8

3,5

77,8

69,7

24,1

23,6

14,2

13,8

Solmittuja avioliittoja keskimäärin vuosittain keskiväkiluvun 10.000 henkeä kohden vv. $1934-1938$

Vuotta nuorempana kuolleita 9/00 elävänä syntyneistä vv. $1941-1944 \ldots \ldots \ldots \ldots \ldots \ldots \ldots$

Huollon (köyhäinhoidon ja laśtensuojelun) varassa olevia keskimäärin vuosittain ${ }^{0} / 00$ keskiväkiluvusta vv. $1940-1944 \ldots \ldots \ldots \ldots$. Veroäyrin keskihinta vv, 1936-1941, mk ......

72,4

69,9

46,5

38,1

$13: 35$

$10: 30$

Useimmissa edellisen yhdistelmän ilmaisemissa seikoissa tutkimuskuntien ja läänin maaseudun kesken ei ole havaittavissa olennaisia eroavuuksia. Se seikka, että tutkimuskunnissa on suhteellisesti huomattavasti enemmän maatalousväestöä kuin läänin koko maaseudulla, on seuraus siitä, että kaikki tutkimuskunnat ovat puhtaita maanviljelys-, etupäässä pienviljelyskuntia, joissa teollisuus on vähäistä, mutta joissa metsätöillä on suuri merkitys väestön toimeentulolle, ja että läänin maaseutuun virallisessa tilastossa on luettu myös Varkau- 
den, Lieksan ja Nurmeksen kauppalat. Kolme viimeistä yhdistelmään sisältyvää vertailua - pikkulasten kuolleisuus, huollettávien määrä ja veroäyrin keskihinta - taas osoittavat, että tutkimuskuntien väestö on jonkin verran köyhempää ja vähemmän edistynyttä, kuin läänin virallisesti maaseutuun luettavan alueen väestö keskitasoltaan on. Lisäksi on avioliittoisuus tutkimuskunnissa ollut suhteellisen vähäinen.

Tutkimuskuntien oloja voitaneen näin ollen pitää tyypillisinä läänin varsinaisille maanviljelysa l u eill e tai ainakin keskitasoa hieman köyhemmille alueille.

\section{Tutkimusaineiston edustavuus.}

Nyt esiteltävä selvitys kohdistui sellaisiin edellä mainituissa kunnissa asuviin perheisiin, jotka $\mathrm{v} u$ on $\mathrm{n}$ a 1945 saivat valtion varoista perhelisälain mukaista $\mathrm{perhel}$ is ää. ${ }^{5}$ Tutkittavat perheet olivat siis sellaisia, joihin kuului vähintään viisi - tai, mikäli perheen pääasiallinen huoltaja oli kuollut tai tullut pysyvästi työkyvyttömäksi, ainakin kolme - perheen huollettavana olevaa 16 vuotta nuorempaa lasta..$^{6}$

Lasten vähimmäismäärän ohella perhelisän saamisen ehtona oli perheen vähävaraisuus siten, että mainittua lisää vuonna 1945 kuntien kalleusryhmityksen ensimmäisessä ryhmässä, johon kaikki tutkimuskunnatkin kuuluivat, saivat ainoastaan sellaiset perheet, joiden vanhemmille ja perhelisään oikeutetuille lapsille viimeksi toimitetussa kunnallisverotuksessa yhteensä maksuunpantu äyriluku ei ollut 310 :ä suurempi tai, mikäli oli kysymyksessä perhe, jonka pääasiallinen huoltaja oli kuollut tai tullut pysyvästi työkyvyttömäksi, suurempi kuin 240. Perheen huollettavana olevien lasten luvun ylittäessä säädetyn vähimmäismäärän äyrirajaa oli korotettava 20 prosentilla kunkin tuon määrän ylittävän lapsen osalta. Huoltolautakunnilla on kuitenkin oikeus harkintansa mukaan myöntää tai kieltää perhelisä edellä mainittujen tulorajojen estämättä, mikäli taloudellisten ym. seikkojen katsotaan sitä vaativan. 
Tutkituille perheille oli siis ominaista kaksi seikkaa: ne olivat lapsiluvultaan ylittä.neet määrätyn rajan, ja ne olivat vähävaraisia. Tärkeätä olisi nyt tutkimuksen yleispätevyyden kannalta voida todeta, moniko sellainen perhe, joka lasten lukumäärän puolesta olisi ollut oikeutettu perhelisän saantiin, tulojensa suuruuden takia on jäänyt siitä osattomaksi. Tietoja tästä ei kuitenkaan ole saatavissa, tietynsuuruisten perheiden lukumäärä maassamme kun ei ole selvillä. Lähtökohdar arvioinnille tarjoaa kuitenkin se seikka, että vuonna 194F perhelisiä Kuopion läänin maalaiskunnissa jaettiin yhteensa 5359:1le viittä tai useampaa perhelisän saantiin oikeutettua lasta huoltavalle perheelle. ${ }^{7}$

Koetettaessa arviointien tietä ratkaista kysymys, su u r e nko osan nämä noin 5350 vähintään viiden lapsen perhelisäperhettä muodostavat kaikista Kuopion läänin malaiskunnissa asuvista vastaavansuuruisista perheistä, on arvioitava viimeksi mainittujen lukumäärä. Tällöin voidaan käyttää hyväksi sitä em. tutkimusta, joka valtion toimesta vuonna 1937 suoritettiin maalaiskuntien asunto-oloista. ${ }^{2}$ Tämä tutkimus oli edustava, mutta tutkitut 56 maan eri osissa sijaitsevaa kuntaa oli valittu siten, että ne »sangen tarkasti kuvastavat koko maaseudun sosiaalisia ja taloudellisia olosuhteita». Tutkimuksessa eri asunnoissa asuvat asumisryhmät oli ryhmitelty myös 15 vuotta nuorempien lasten luvun mukaan. Vähintään viisi lasta käsittäviä asumisryhmiä eli siis normaalitapauksessa perheitä oli asuntotutkimuksessa tutkituissa Kuopion läänin kunnissa kaikkiaan 392. Jos otaksutaan suuria perheitä muissakin läänin maalaiskunnis่sa olleen samassa suhteessa niiden asukaslukuun verrattuna kuin tutkituissakin kunnissa, saadaan ottaen perustaksi henkikirjoitetun väestön määrän vuoden 1937 alussa tulokseksi, että perheitä, joissa oli ainakin viisi 15 vuotta nuorempaa lasta, oli vuonna 1937 Kuopion läänin kaikissa maalaiskunnissa yhteensä $5847 .^{8}$

Kun nyt otetaan lisäksi huomioon, että läänin maaseudun henkikirjoitetun väestön määrä vuodesta 1937 vuoteen 
1945 on kasvanut $4,75 \%: 11 a^{9}$, saadaan ko. perheiden luvuksi viimeksi mainittuna vuonna karkeasti arvioiden noin 6125. Tämä luku tarkoittaa siis perheitä, joissa oli vähintään viisi 15 vuotta nuorempaa lasta. Kun perhelisän saamisen ehtona oleva ikäraja kuitenkin on korkeampi, nim. 16 vuotta $^{6}$, olisi nyt arvioitava, paljonko oli sellaisia perheitä, joihin kuului vähintään viisi 16 vuotta nuorempaa lasta. Tämä saataisiin lasketuksi lisäämällä em. lukuun (6125) sisarusparvessaan järjestysluvultaan viidensien 15-vuotiaiden lasten luku. Tätä lukua ei tunneta, mutta likimääräinen arvio saadaan, kun läänin maaseudun läsnäolevaan väestöön vuonna 1940 sisältyneet 7617 15vuotiasta kerrotaan 8,84 \%:lla, mikä luku ilmaisee, suuriko osa läänin maaseudulla syntyneistä aviolapsista oli järjestysluvultaan viidensiä vuosina $1941-1943$, miltä ajalta tällaisia tietoja on saatavissa. ${ }^{10}$ Täten saadaan luku 673 , joten siis vähintään viisi 16 vuotta nuorempaa lasta käsittävien Kuopion läänin maaseudulla asuvien perheiden arvioluvuksi tulee 6800 .

Tämä luku (6800) on verrattain karkean arvioinnin tulos, eikä sitä voi pitää tarkkana. Asetettaessa sen rinnalle perhélisäperheiden määrä, 5350, mikä siitä muodostaa lähes 80 prosenttia, voitaneen kuitenkin ainakin sanoa, että neljästä Kuopion läänin maaseudulla asuvasta perheestä, joihin kuuluu vähintään viisi 16 vuotta nuorempaa lasta, on vain yksi sellainen, joka ei nauti perhelisää. Näin ollen perhelisän sa nnin edellytyksenä oleva tuloraja ei aiheuta, etteivätkö perhelisäperheiden olot olisi tyypillisiä Kuopion läänin monilapsisten perheiden suurimmalle os alle.

Tutkimusaineistoon sisältyi kuitenkin joitakin pienempiäkin perheitä, nim. sellaisia, joiden pääasiallinen huoltaja oli kuollut ja joissa oli vähintään kolme 16 vuotta nuorempaa lasta, mutta tällaisia kolmen - neljän lapsen perheitä oli vain 56 eli 13,1 \% koko aineistosta, 427:stä. Mainituistakin perheistä oli vain 27 eli $6,3 \%$ koko aineistosta sellaisia, joissa kaikkiaan, ikään katsomatta, oli vain kolme tai neljä lasta. Ns. leskiperheiden mukaan ottaminen ei täten suures- 
tikaan horjuta aineiston lasten lukumäärään perustuva homogeenisuutta.

Aineiston täydellisyyteen vaikuttaa vielä se, suuriko osa niistä perheistä, jotka ominaisuuksiensa puolesta kuuluivat tutkittavana olevaan joukkoon, tosiasiallisesti on jäänyt tutkimuksen ulkopuolelle. Kun tutkimus toimitettiin siten, että tietojenkerääjät ensin, kesäkuun lopulla, kuntien huoltolautakuntien ns. perhelisäkortistoista poimivat tutkittavien perheiden nimet, ts. niiden perheiden, jotka vuoden 1945 kuluessa jo olivat saaneet perhelisää, jäivät tutkimatta kaikki ne perheet, jotka jättivät perhelisähakemuksensa myöhemmin, niin ettei heille vielä siihen mennessä ollut perhelisää annettu. Tällaisiin perheisiin kuuluivat mm. ne, joissa vasta kesän tultua oli sattunut sellainen tapaus, esim. viidennen alaikäisen lapsen syntyminen tai perheen huoltajan kuolema, mikä saattoi olla aiheeena perhelisän hakemiseen. Tällaisten perheiden tutkimatta jääminen vaikutti siis tutkimusaineistoon siten, että siitä jäi pois etupäässä pienimpiä mahdollisia perheitä.

Seuraava yhdistelmä, josta ilmenee tutkittujen perheiden määrä ja jakaantuminen eri kuntien dsalle, sisältää myös tiedon siitä, monelleko perheelle ko. kunnissa vuoden 1945 kuluessa kaikkiaan on myönnetty perhelisää. ${ }^{7}$ Luvut on ilmoitettu erikseen ns. suurista perheistä (perheistä, jotka ovat saaneet perhelisää viidennestä alaikäisestä lapsesta lähtien) ja erikseen ns. leskiperheistä (perheistä, joiden pääasiallinen huoltaja on kuollut tai tullut pysyvästi työkyvyttömäksi ja jotka ovat saaneet lisää kolmannesta alaikäisestä lapsesta alkaen).

Tutkittuja perheitä

Suuria Leski- Yhteensä
Perhelisäperh. kaikkiaan

ä Suuria Leski- Yhteensä Kunta perheitä perheitä

a

Tuusniemi

Muuruvesi

Nilsiä

Vieremä

Yhteensä

b
78
55
141
77
351

351

78

141

77

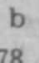

$b$
8
7
1

$c$
6
13
39
18
76

perheitä perheitä

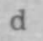

84

68

180

95

427

e
106
63
159
104
432

e

106

159

104

432

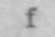

14

14

43

27

98

d\% g:stä
h
70,0
88,3
89,1
72,5
80,6


Tutkimuskunnissa joutui siis $4 / 5 \mathrm{k}$ a i k is t a perhel is ä ä saaneista perheistä selvittelyn kohteeksi. Leskiperheitä tutkituista perheistä oli $17,9 \%$ vastaavan luvun kaikista perhelisäperheistä ollessa 18,5\%. Kaikki tutkitut ns. leskiperheet olivat sellaisia, joissa perheen pääasiallisena huoltajana ollut mies oli kuollut.

Johtopäätöksenä tutkittujen kuntien ja tutkimusaineiston edustavuudesta edellä esitetystä voitaneen sanoa, että $t u t k i-$ musaineisto on riittävän täydellinen, jotta siihen perustuvaa kuva a Kuopion läänin maatalousalueiden suurten ja keskisuurten perheiden surimman osan-ja samalla köyhimmän osan - oloista voidaan pitää tyypillise$n$ ä.

Selvityksen tulosten esittely.

Koska tutkittuja perheitä tässä tutkimuksessa on pidetty Kuopion läänin koko maaseudun perhelisäperheitä edustavina on seuraavassa esityksessä käsitelty tutkimusaineistoa vain yhtenä ryhmänä, eikä ole tietoja eri kuntien osalta vertailtu keskenään. Jos alkuaineistosta laadittuja tilastotauluja, joissa tíedot on esitetty kunnittain, tarkastellaan, todetaan, ettei tutkittujen eri kuntien kesken ole havaittavissakaan mitään olennaisia eroavuuksia tutkittujen kysymysten suhteen. Näitä 29 taulua ei kuitenkaan ole katsottu tarpeelliseksi painattaa, mutta ovat ne samoinkuin tutkimuksen kyselylomakekin nähtävissä Väestöpoliittisen Tutkimuslaitoksen kirjastossa.

\section{PERHEET.}

\section{Ammattiryhmitys.}

Ensiksi on syytä tarkastella kysymystä, missä määrin tutkittujen perheiden huoltajien jakaantuminen eri ammattiryhmiin oli samanlainen kuin läänin maaseudulla yleensä. Suoritettaessa tällaista vertailua ei tässä ole käytetty virallisen tilaston ns. 
kymmenvuotistaulustoihin sisältyvää selvitystä ammattiryhmityksestä ${ }^{11}$, koska siinä perhettä ei ole käytetty yksikkönä, vaan on samaan ryhmään luettu perheiden päähenkilöt ynnä yksityiset itsenäiset päähenkilöt. Kun vuoden 1937 maaseudun asuntotutkimuksessa kuitenkin asumisryhmät on jaoiteltu myös ammateittain ${ }^{12}$ ja kun asumisryhmien ja perheiden luku ei suurestikaan poikenne toisistaan, voidaan ko. vertailu suorittaa. Käytetty ammattiryhmitys on seuraava:

- 1. Tilanomistajia ja tilallisia (peltopinta-ala yli $10 \mathrm{ha}$ ).

2. Pienviljelijöitä (peltopinta-ala 10 ha tai vähemmän) ja kalastajia ${ }^{18}$.

3. Muonamiehiä, renkejä ${ }^{14}$, työnjohtajia.

4. Muuta maataloustyöväkeä.

5. Kauppiaita ${ }^{15}$, tehtailijoita, itsenäisiä käsityöläisiä ym. yrittäjiä.

6. Virkamiehiä ${ }^{16}$, opettajia ${ }^{17}$ ym.

7. Teollisuus- ja kuljetustyöväkeä, kauppa-apulaisia ${ }^{14}$ ym.

8. Metsä- ja tietyöläisiä, sekatyöläisiä.

9. Syytinkiläisiä ${ }^{14}$, eläkkeellä olevia henkilöitä ${ }^{14}$.

10. Muita päähenkilöitä ${ }^{18}$.

Miten toisaalta tutkitut perheet ja toisaalta läänin maaseudun perheet yleensä jakaantuivat eri ammattiryhmiin, käy ilmi seuraavasta asetelmasta.

\begin{tabular}{|c|c|c|c|c|c|c|c|c|c|c|c|}
\hline & \multicolumn{10}{|c|}{ Ammattiryhmä } & $\begin{array}{l}\text { Yh- } \\
\text { teen- }\end{array}$ \\
\hline & 1 & 2 & 3 & 4 & 5 & 6 & 7 & 8 & 9 & 10 & sä \\
\hline $\begin{array}{l}\text { utkitut perhelisä- } \\
\text { perheet, luku . }\end{array}$ & 19 & 190 & 13 & 12 & 24 & 2 & 18 & 137 & & 12 & 427 \\
\hline Samat, $\% \quad \ldots \ldots$ & 4,5 & 44,5 & 3,0 & 2,8 & 5,6 & 0,5 & 4,2 & 32,1 & - & 2,8 & 100,0 \\
\hline perheet, $\%$ & 25,6 & 34,5 & 3,5 & 3,8 & 4,4 & 5,0 & 7,0 & 14,8 & 0,9 & 0,5 & 100,0 \\
\hline
\end{tabular}

Kuopion läänin maaseudulla tulee siis pienviljelijäin ja metsätyöläisten perheistä-tutkimuksessa vallitsevista perheistä - su urempi os a $k u$ in muihin ammattiryhmiin kuuluvista perheistä perhelisistä osalliseksi, kun taas varsinaiset ti- 
lanomistajat ja tilalliset sekä virkamiehet, opettajat ym. jäävät yleensä niitä vaille. Tätä tulosta vahvistaa myös seuraava yhdistelmä, jossa tämän tutkimuksen tuloksia on verrattu sosiaaliministeriössä laadittuun tilastoon Kuopion läänissä vuonna 1945 perhelisää saaneista perheistä ${ }^{19}$ perustuviin suhdelukuihin. Koska jälkimmäisen tilaston ammattiryhmitys oli erilainen kuin tässä tutkimuksessa käytetty, on eräitä ryhmiä tạ̈tynyt yhdistää.

Ammattiryhmät
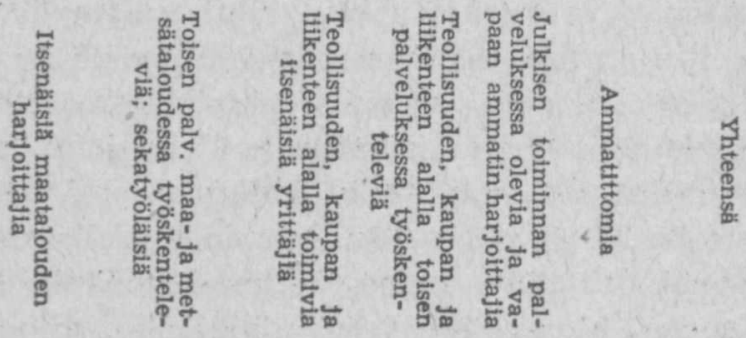

em. ryhmityk-

sen numeroinnin mukaan

Tutkitut perhe-

lisäperheet, $\%$

Kaikki perhelisäperheet Kuopion läänissä, $\%$

$1+2 \quad 3+4+8$

5

7

$6 \quad 9+10$

$49,0 \quad 37,9$

5,6

4,2

0,5

2,8

100,0

Olennaiset eroavuudet edellä olevan asetelman ilmaisemissa luvuissa rajoittuvat siis siihen, että sosiaaliministeriön tilastossa ammatittomien ryhmä on suurempi kuin nyt käsiteltävänä olevassa tutkimuksessa, kun taas asianlaita maa- ja metsätyöväestöön sekä sekatyöläisiin nähden on päinvastainen.

Edellä kävi selville, että etupäässä pienviljelijäin ja metsätyöläisten perheet saavat perhelisiä, mutta että peltopinta-alaa 10 ha enemmän omistavista perheistä vain hyvin harvat tulevat lisistä osallisiksi. Tämä ei useassakaan tapauksessa johdu siitä, että tilallisten perheet olisivat pieniä, vaan siitä, että vähänkin suurempien tilojen veroäyrimäärät ylittävät perhelisän saamisen ehtona olevan rajan. Jos nimittäin tarkastellaan esim. 
niitä ohjeita ja määräyksiä, joita valtioneuvosto ja valtiovarainministeriö ovat antaneet maatalouskiinteistöistä saatujen tulojen taksoituksessa vuonna 1944 noudatettavista verotusperusteista, jotka tulivat vaikuttamaan perhelisiä vuoden 1945 alkupuolella myönnettäessä, todetaan, että niiden mukaan tutkituissa kunnissa esim. 13 ha viljeltyä maata ja 100 ha metsämaata omistavan viiden alaikäisen lapsen perheen veroäyrimäärä kohosi 313:een, joten perhe ei ollut oikeutettu perhelisän saantiin. Jos sensijaan olisi ollut kysymyksessä perhe, jossa mainittujen lasten lisäksi olisi ollut vielä kotona työskentelevä 16-vuotias poika, ei samanlaista viljeltyä maata olisi tarvinnut olla kuin 8 ha ja metsämaata 35 ha, jotta veroäyrien vähimmäismäärä, 310 , olisi tullut ylitetyksi. Jos tarkasteltaisiin sellaisia perheitä, joissa olisi enemmän alaikäisiä lapsia, nousisivat mainitut pinta-alojen vähimmäismäärät, koska perhelisän saamisen ehtona oleva veroäyrimääräkin silloin kohoaisi ja verotuksen lapsivähennykset suurenisivat. ${ }^{20}$

Sellaisia perheitä, joissa päähenkilönä oli nainen, oli aineistossa 76 eli 17,8\% kaikista perheistä. Yleisimpiä tällaiset perheet olivat maataloustyöläisten ja ammatittomien keskuudessa. Viimeksi mainittu ryhmä käsittikin yksinomaan leskiäitejä.

\section{Lapsiluku.}

Vaikka tämän tutkimuksen aineistoon sisältyvät pienimmät ammattiryhmät ovatkin niin suppeita, ettei perheiden vähälukuisuudesta johtuen niiden perusteella voi tehdä yleisiä johtopäätöksiä lapsiluvusta eri ammattiryhmissä, on nämäkin tiedot eri kuntien osalta laskettu. Tällöin on otettu huomioon ainoastaan 15 vuotta nuoremmat lapset. Näin on menetelty, jotta voitaisiin suorittaa vertailua läänin maaseudun oloihin yleensä. Perheiden suuruutta eri ammattiryhmissä Suomessa valaisevista tutkimuksista on nim. tässä vertailuun käytettäväksi tarkoituksenmukaisin maaseudun asuntotutkimukseen sisältyvä tilasto eri yhteiskuntaryhmien asunnoista lapsiluvun 
mukaan, ja tässä on otettu huomioon ainoastaan 15 vuotta nuoremmat lapset. ${ }^{21}$ Vertailun tulos muodostuu seuraavanlaiseksi.

Lapsia keskimäärin perhettä kohden ammattiryhmässä

Tutkitut perhelisäperheet

Läänin maaseudun perheet

$\begin{array}{llllrr}1 & 2 & 3 & 4 & 5 & 6\end{array}$

$5,6 \quad 5,2 \quad 5,3$

4,5

5,2

6,0

$5,0 \quad 5,1$

$\begin{array}{lll}2,1 & 1,9 & 1,7\end{array}$

$1,4 \quad 1,2$

$0,7 \quad 1,5$

2,1

$\begin{array}{lll}0,3 & 1,0 & 1,8\end{array}$

Alempi lukusarja osoittaa, että lasten lukumäärä Kuopion läänissä yleensäkin on suurin juuri nliissä ammattiryhmissä, pienviljelijäin ja metsätyöläisten keskuudessa, joihin kuuluvat perheet saavat eniten perhelisiä, vain sillä rajoituksella, että v a rsinaiset tilalliset, joiden keskuudessa perheet ovat kaikkein suurimmat, eivät yleensä varallisuutensa vuoksi saa perhelisää, kuten edellä (s. 157) on esitetty. Vertailun vuoksi mainittakoon tässä vielä, että vuonna 1946 Jokioisten kunnassa suoritetun tutkimuksen mukaan oli eri ammattiryhmiin kuuluvissa perheissä, joiden äidit olivat $40-60$-vuotiaita, lasten keskimääräinen lukumäärä: virkamiesten perheissä 2,41 , tehdastyöläisten 2,76 , maanviljelijäin 4,26 ja maataloustyöläisten perheissä $4,21 .^{22}$

Tutkittujen perheiden keski määr äine n lasten lu$\mathrm{k}$ u mä ä rä oli ottaen huomioon $\mathrm{ka} \mathrm{i} \mathrm{k} \mathrm{ki} \mathrm{aviopuolisoilla} \mathrm{olleet}$ omat lapset 7,5 (vaihdellen eri kunnissa 7,0 :n ja $7,7: n$ välillä). Vastaava luku, joka koskee vielä el os s a olleit a omia lapsia näiden iästä rippumatta, oli 6,7 (vaihdellen 6,4:stä 6,9:ään). Perheitä, joissa on ollut kaikkiaan 18 omaa lasta, oli Nilsiässä 2, ja toisessa näistä oli vieläkin elossa 16 lasta. Lukuisimmin $(18,3 \%)$ olivat tutkittujen perheiden keskuudessa edustettuina sellaiset perheet, joissa/on ollut kaikkiaan 6 lasta ja $(22,7$ \% $)$ sellaiset perheet, joissa nykyään on elossa 5 omaa lasta. Tämä onkin luonnollista, koska perhelisän saamisen ehtona vuonna 1945 oli (lukuunottamatta sellaisia perheitä, joissa pääasiallinen huoltaja oli kuollut) ainakin viiden alaikäisen lapsen elättäminen. Numeroita lähemmin tarkasteltaessa havaitaan 
siirryttäessä 9-10 lapsen perheistä sitä suurempiin perheisiin lukumäärän jyrkästi laskevan. Sellaisia perheitä, joissa on ollut enemmän kuin 10 lasta, oli tutkituista perheistä 9,8\%. H yvin suuria perheitä on siis Kuopion läänissäkin nykyään vain harvassa.

Lähes joka toisessa $(47,1 \%)$ kaikista tutkituista perheistä oli ku ollut ainakin yksi oma lapsi. Joka viidennestä (21,8 \%) oli kuollut kaksi lasta tai enemmän. Keskimäärin oli perheistä kuollut 0,8 lasta (vaihdellen eri kunnissa 0,6:sta 0,9:ään).

Yksi otto-tai kasvattilapsi oli Tuusniemellä kahdessa ja Nilsiässä viidessä perheessä.

Isovanhempien kodin lapsiluku.

Kyselylomakkeessa tiedusteltiin myös, montako lasta erikseen ko. perheen isän ja erikseen äidin vanhemmilla oli ollut. Yleisimmin esiintyvä tapaus oli sellainen, että isän ja äidin vanhemmilla oli ollut $7-9$ lasta, joten nyt tutkittujen suurten perheiden vanhemmat olivat yleensä itsekin syntyisin surista perheistä.

Miten suuriperheisyys vanhemmankin polven-keskuudessa Kuopion läänissä on ollut yleisempää kuin etelämpänä, käy ilmi seuraavasta yhdistelmästä, jossa tätä asiaa on valaistu paitsi Kuopion läänin myös Helsingin suurten perheiden ${ }^{23}$ osalta.

Perheitä, joiden molemmilla isovanhemmil-

la on ollut vähintään 10 lasta ......... Perheitä, joiden molemmilla isovanhemmilla on ollut vähintään 7 lasta $\ldots \ldots \ldots \ldots$. Perheitä, joiden toisella isovanhemmalla on ollut ainakin 10 lasta ............... Perheitä, joiden molemmilla isovanhemmilla on ollut vähintään 4 lasta ........... Perheitä, joiden toisella isovanhemmalla on ollut ainakin 7 lasta ............... Perheitä, joiden toisella isovanhemmalla on ollut ainakin 4 lasta ...............

$\begin{array}{cc}\begin{array}{c}\text { Tutkitut } \\ \text { perhelisä- } \\ \text { perheet, } \\ \%\end{array} & \begin{array}{c}1943 \text { tutkitut } \\ \text { tering suuret } \\ \text { perheet, } \\ \%, 8\end{array} \\ 42,0 & 5,2 \\ 42,0 & 29,9 \\ 83,0 & 32,7 \\ 84,9 & 69,2 \\ 98,9 & 72,7 \\ & 96,7\end{array}$




\section{ASUNTO-OLOT.}

Seikkaperäisintä nyt selostettavassa tutkimuksessa oli perheiden asunto-olojen selvittely, koska edellä useaan otteeseen mainittu maaseudun asuntotutkimus tarjosi tässä suhteessa sopivaa vertailuaineistoa. Seuraavassa esitetty asunto-olojen vertailu tutkittujen perhelisäperheiden ja läänin maaseudullà yleensä vallitsevien asuntoolojen kesken tapahtuukin kokonaan mainitun virallisen asuntotutkimuksen pohjalla. ${ }^{24}$ Viimeksi mainittu tutkimus on tosin suoritettu jo vuonna 1937, minkä jälkeen asunto-olot maaseudullakin ovat rakennustoiminnan pysähtymisen ja siirtoväen asuttamisen vuoksi suuresti kiristyneet, joten tämä seikka heikentää vertailun pätevyyttä. Voitaneen kuitenkin edellyttää, että useimmat tutkituista perheistä, siirtoväkeen kuuluvaa vähäistä osaa lukuunottamatta, ovat asuneet nykyisissä asunnoissaan jo ennen sotia 1939 - 1945, maaseudun suuret perheet kun eivät usein muuta asuntoa, ja että asunto-oloissa tapahtunut kehitys ei siis nyt kysymyksessä olevaan ryhmään, perhelisäperheisiin, nähden riistä mainitunlaiselta vertailulta pohjaa. Huomattava siis vain on, että Kuopion läänin maaseudun asuntooloista yleensä tässä tutkimuksessa annettu kuva tarkoittaa sotien edellistä aikaa.

Asuntojen hallintamuoto.

Asunto-oloja käsiteltäessä on tärkeätä ensinnäkin selvittää, miten yleisiä ovat omalla maalla ja miten yleisiä vuokramaalla sijaitsevat omat asunnot ja miten yleisiä taas vuokralla olevat asunnot. Tässä suhteessa saadaan rinnastettaessa tutkitut perheet ja läänin maaseudun perheet yleensä seuraavanlaiset yhdistelmät, joista ensimmäisestä näkyy vuokralla asumisen yleisyys ja toisesta taas, miten suuri osa omista asunnoista sijaitsi omalla maalla ja miten suuri osa vuokramaalla. 
Asuntoja, joiden haltijana

oli rakennuksen

omistaja vuokralainen

Tutkitut perhelisäperheet;

luku

Samat

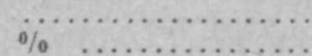

Läänin maaseudun perheet, $\% \quad \ldots \ldots \ldots \ldots \ldots \ldots$

$\begin{array}{llll}325 & 97 & 5 & 427 \\ 76,1 & 22,7 & 1,2 & 100,0 \\ 70,3 & 29,7 & - & 100,0\end{array}$

\section{Omistajain käyttämiä asuntoja}

rakennuksissa, jotka

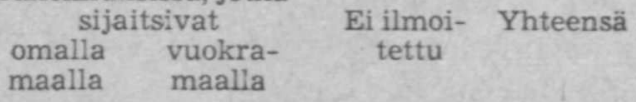

Tutkitut perhelisäperheet, luku ............... 306

Samat, $\%$. . . . . 92,7

$06 \quad 19$

Läänin maaseudun perheet, $\%, \ldots \ldots \ldots \ldots \ldots \ldots \ldots, \quad 90,5$

19

5,8

9,5
5

1,5

330

100,0

100,0

Kuopion läänin perhelisäperheiden keskuudessa ei siis vuokralla-asuminen eikä maankaan pitäminen vuokralla ollut niin yleistä kuin yleensä maaseudulla. Onkin luonnollista, että näin on laita, kun on kysymys suurista perheistä, joiden asuminen yleensä on vakinaisempaa kuin pieniperheisten ja etenkin perheettömien.

Asuntojen mukavuudet, lisätilat ja kunto.

Asuntojen asumiskelpoisuuteen vaikuttaa suuresti veden s a a n ti. Millaisia tutkittujen perheiden asunnot tässä suhteessa olivat verrattuina läänin maaseudun asuntoihin, käy ilmi seuraavasta asetelmasta.

Vedenottopaikkana

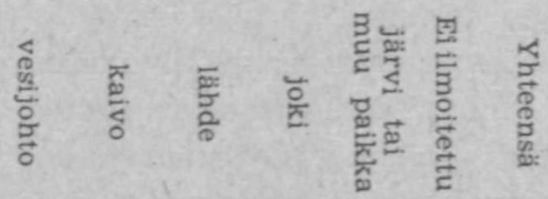

$\begin{array}{llllllllll}\text { Tutkitut perhelisäperheet, luku } & 8 & 190 & 153 & 21 & 53 & 2 & 427\end{array}$ Samat, $\% \ldots \ldots \ldots \ldots \ldots \ldots \ldots \ldots \ldots \quad 1,8 \quad 44,5 \quad 35,8 \quad 5,0 \quad 12,4 \quad 0,5 \quad 100,0$ Läänin maaseudun perheet, $\% \quad \ldots \quad 3,6 \quad 73,4 \quad 12,3 \quad 1,7 \quad 9,0 \quad-\quad 100,0$ 
Se seikka, että $44,5 \%$ tutkituista perheistä on ilmoitettu käyttäneen vedenottopaikkanaan kaivoa ja $35,8 \%$ lähdettä, kun sitävastoin luvut läänin maaseudulla yleensä vuonna 1937 olivat $73,4 \%$ ja $12,3 \%$, viittaa siihen, että osaa niistä vedenottopaikoista, jotka tässä tutkimuksessa on luettu lähteiksi, maaseudun asuntotutkimuksessa on pidetty kaivoina. Oikeamman kuvan asiasta siis saa, kun toteaa, että tutkituista perheistä 80,3\% nouti veden kaivosta tai lähteestä ja $17,4 \%$ joesta, järvestä tai muusta sellaisesta paikasta vastaavien lukujen läänin koko maaseudulla ollessa $85,7 \%$ ja $10,7 \%$. Näin ollen perhelisäperheet ovat tässä suhteessa epäedullisemmassa asemassa, kuin yleensä maaseudulla on asianlaita. Luonnollista on, että perhelisäperheissä, vähävaraisissa perheissä, myös vesijohdot ovat tavallistakin harvinaisempia.

Veden saannin helppoutta ei kuitenkaan kuvasta yksin se, millainen vedenottopaikka on, vaan olisi sen lisäksi tarpeen tietää sen kunto, onko se vähävetinen jne. Näistä seikoista tämä tutkimus ei kuitenkaan anna valaistusta, mutta sen sijaan kyllä vedenhakupaikan etäisyydestä. Tiedot tästä sisältyvät seuraavaan yhdistelmään. ${ }^{25}$

\section{Vedenottopaikan et. ulko- ovelta, $\mathrm{m}$}

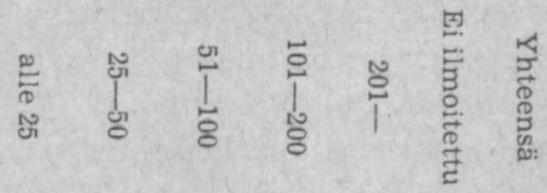

$\begin{array}{lllllllll}\text { Tutkitut perhelisäperheet, luku } & 94 & 131 & 89 & 51 & 49 & 5 & 419\end{array}$

$\begin{array}{llllllll}\text { Samat, } \% \ldots \ldots \ldots \ldots \ldots \ldots \ldots & 22,4 & 31,3 & 21,2 & 12,2 & 11,7 & 1,2 & 100,0\end{array}$

Läänin maaseudun perheet, $\% \ldots \begin{array}{lllllll}\% 1,2 & 43,3 & 15,0 & 6,8 & 3,5 & 0,2 & 100,0\end{array}$

Vedenhakumatkan pituuden suhteen olot perhelisäperheiden keskuudessa siis ovat hyvin takapajulla. Kun noin joka toinen tutkittu perhelisäperhe $(45,1 \%)$ nouti veden 50 metriä kauempaa, oli samanlaisessa asemassa ainoastaan joka neljäs $(25,3 \%)$ läänin maaseudulla asuvista asumisryhmistä. Perhelisäperheistä useamman kuin joka kymmenennen $(11,7 \%)$ oli pakko hakea 
vesi 200 metriä etäämpänä olevasta vedenottopaikasta. Vedennoutomatkan keskimääräinen pituus tutkittujen perheiden osalta oli 107 metriä.

Olojen edistyneisyys erinäisten m u kavu u ki en ja lisätilojen suhteen käy ilmi seuraavasta asetelmasta.

Asuntoja, joista puuttui

\begin{tabular}{|c|c|c|c|c|c|c|}
\hline 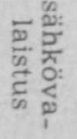 & 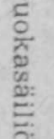 & 产 & 离 & $\underset{\Xi}{\stackrel{\varpi}{\vec{D}}}$ & 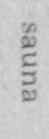 & 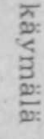 \\
\hline
\end{tabular}

Tutkitut perhelisäper-

heet, luku .........

Samat, $\%$............

Läänin maaseudun perheet, $\%$..........

$\begin{array}{cccccccc}385 & 107 & 327 & 376 & 199 & 57 & 60 & 192 \\ 90,2 & 25,1 & 76,6 & 88,1 & 46,6 & 13,3 & 14,1 & 45,1) \\ 92,4 & 12,2 & 60,3 & 75,9 & 40,5 & 10,6 & 16,8 & .\end{array}$

Verrattaessa toisaalta tutkittujen perhelisäperheiden ja toisaalta läänin maaseutuperheiden oloja asunnon mukavuuksien suhteen todetaan edellä esitettyjen numerojen valossa edellisten jäävän vertailussa huonommalle puolelle, mitä tulee saunan, ruokasäiliön, vaatesäiliön, aitan ja ruokataloudessa tärkeän kellarin yleisyyteen. Vaatesäiliön ja aitan todettiin muuten maaseudun asuntotutkimuksessa osittain korvaavan toisiaan, sillä niissä osissa maata, joissa aitat olivat yleisiä, oli säiliöitä vähemmän, ja päinvastoin.. ${ }^{26}$ Vain käymälän yleisyys ọli hiukan suurempi perhelisäperheissä kuin läänin maaseudulla yleensä. Sähkövalaistusta koskevat numerot taas eivät keskenään verrattuina anna oloista oikeaa kuvaa, koska tämä tutkimus ja maaseudun asuntotutkimus käsitti osittain eri kuntia Kuopion läänissä ja koska sähkövalaistuksen yleisyys asunnoissa on riippuvainen ko. kunnan sähköistyksen asteesta.

Seuraava asetelma, josta näkyy, suuriko osa sellaisista asunnoista, joihin liittyi kellari, oli varustettu e rillisillä kellareilla, osoittaa, että Kuopion iäänin tutkittujen perhelisäperheiden keskuudessa ei erillinen kellari ollut niin tavallinen kuin läänin maaseudulla yleensä. 
Asuntoja, joihin liittyi

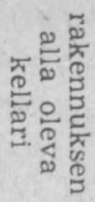

Tutkitut perhelisäperheet, luku $\ldots . .23$

Samat, $\%$.................. 45,2

Läänin maaseudun perheet, $\% \ldots \ldots \quad 36,0$

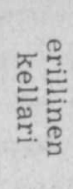

27

52,9

57,8

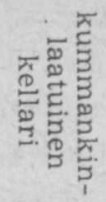

$$
\text { : }
$$

51

1,9

6,2
100,0 100,0

Tutkituissa asunnoissa oli erillisen kellarin keskimääräinen etäisyys ulko-ovelta 32 metriä.

Tutkimuksessa luokiteltiin asunnot myös niiden $\mathrm{k} \mathrm{u} \mathrm{n} \mathrm{n} \mathrm{o} \mathrm{n,}$ kosteuden ja kylmyyden mukaan. Tietyn asunnon sijoittaminen näissä suhteissa tiettyyn ryhmään on luonnollisesti enemmän tai vähemmän subjektiivista, koska kaiken omakohtaisen arvioinnin ja arvostelun tarpeettomaksi tekeviä ohjeita ei voida antaa. Tällaisen subjektiivisuuden haittoja tosin jossakin määrin lieventää se, että kussakin neljästä kunnasta toimi eri tietojenkerääjä. Kuten seuraava yhdistelmä osoittaa, onkin tämän selvityksen tietojenkerääjäin arviointeihin perustuva kuva tutkittujen asuntojen kunnosta suunnilleen yhtäpitävä maaseudun asuntotutkimuksen tulosten kanssa.

Asuntoja, joiden kunto oli

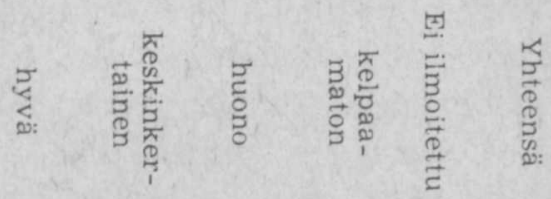

$\begin{array}{llllllll}\text { Tutkitut perhelisäperheet, luku } & 80 & 210 & 101 & 28 & 8 & 427\end{array}$

Samat, $\% \quad \ldots \ldots \ldots \ldots \ldots \ldots \ldots \ldots .18,7 \quad 49,2 \quad 23,6 \quad 6,6 \quad 1,9 \quad 100,0$

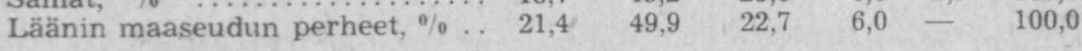

Asunnon asumiskelpoisuuteen vaikuttavat olennaisesti sen lämpö- ja kosteussuhteet. Seuraava asetelma osoittaa selvityksen tulokset tässä suhteessa. 
Asuntoja, jotka olivat

\begin{tabular}{|c|c|c|c|c|c|}
\hline & 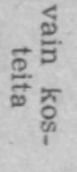 & $\frac{0}{3}$ & 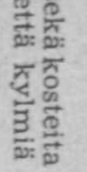 & 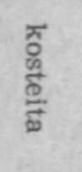 & $\frac{\pi}{\frac{\pi}{3}}$ \\
\hline Tutkitut perhelisäperheet, luku . & 26 & 66 & 134 & 160 & 200 \\
\hline$\ldots \ldots \ldots \ldots \ldots \ldots$ & 6,1 & 15,5 & 31,4 & 37,5 & 46,9 \\
\hline Läänin maaseudun perheet, $\%$. & 3,3 & 12,7 & 17,5 & 20,8 & 30,2 \\
\hline
\end{tabular}

Tämän tutkimuksen tietojenkerääjät ovat siis arvostelleet perhelisäperheiden asunnot kosteuden ja kylmyyden suhteen varsin epäedullisiksi ja siis sangen epäterveellisiksi. Kylmyys näyttää olevan yleisemmin esiintyvä epäkohta kuin kosteus, ja vielä useammin esiintyvät sekä kosteus että kylmyys yhdessã. Maaseudun asuntotutkimuksessa todettiin, että Kuopion läänissä yleinen asuntojen kosteus on maakosteutta, mikä johtuu asuntojen multiaisalustasta. ${ }^{27}$

Paljon puhuvina esimerkkeinä asuntojen huonosta kunnosta mainittakoon seuraavat tietojenkerääjäin antamat lausunnot eräistä tutkimistaan asunnoista. \Kuvaavaa, että talvella yhden (asukkaan) pitää olla tulta pitämässä yölläkin, etteivät kaikki paleltuisi.» Asunto kerrassaan kelvoton: lattiassa suuret raot, katto vuotaa. Uuni huono. Talvella vesi jäätyy sisällä, nurkat kuurassa, noustaan yöllä lämmittämään. (Vieremä.) »Huone on tuskin enää asuttavassa kunnossa. Lattia on vaarallisella tavalla rikkonainen, seinät kovin hatarat ja katto vuotaa. Talvella asunto on lisäksi niin kostea, että pöydät ja vuodevaatteet tulevat märiksi, varsinkin, jos vuoteet ovat välittömässä seinän läheisyydessä. Lisäksi huoneen ilma pilaantuu homeisista seinistä. - Tässä huoneessa perhe kuitenkin joutuu asumaan luultavasti jatkuvasti, sillä uutta asuntoa ei ole tiedossa ja talo, jonka maalla asunto sijaitsee, ei korjaa sitä.» »Asunto on talvella hyvin kylmä lattian ja seinäin hataruuden vuoksi.» »Asunto on rakennettu multiaisille ja on talvella hyvin kylmä. Lattiavetoa on kovasti. Seinät homehtuvat talvella 
kosteudesta.» »Asunto nykyisessä kunnossaan on sangen huono. Uuni savustaa, lattia on harva, samoin seinät. Talvisin mökin katto on kosteuden vuoksi homeen peittämä, nurkat ja akkunat ovat kuurassa.» (Muuruvesi.) »Huone erotettu matalalla pahviseinällä suuremmasta. Talvella kylmä ja kovin vetoinen, seinät homehtuneet.» (Nilsiä.)

Kun maaseudun asuntotutkimuksen mukaan vuonna 1937 Kuopion läänin maaseudun pienasunnoista (asunnoista, joissa oli enintään 2 lämmitettävää huonetta ja keittiö) $6,4 \%$ oli sellaisia, joista puuttui eteinen, oli tämän tutkimuksen mukaan vastaava lukú Kuopion läänin perhelisäperheiden keskuudessa vain $2,8 \%$.

Asuntojen huoneluku ja pinta-ala.

Perustava merkitys asunto-oloja arvosteltaessa on asuntojen huoneluvulla ja pinta-alalla. Millaisia tutkitut asunnot $\mathrm{h}$ u oneluvulta a n olivat, kun otetaan huomioon vain kiinteillä lämmityslaitteilla varustetut huoneet sekä tupa ja keittiö, osoittaa seuraava vertaileva yhdistelmä.

Asuntoja, joissa huoneiden luku oli

Tutkitut perhelisä-

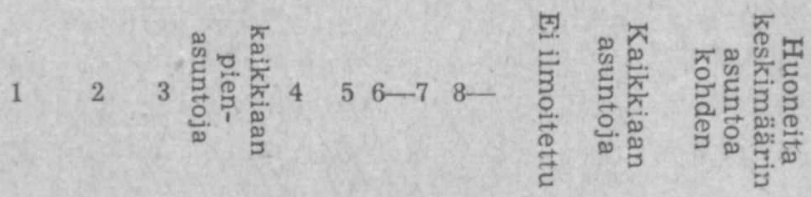

$\begin{array}{llllllllllll}\text { perheet, luku } & 184 & 177 & 41 & 402 & 18 & 2 & - & - & 5 & 427 & \\ \text { amat, } \% & 43,1 & 41,4 & 9,6 & 94,1 & 4,2 & 0,5 & - & - & 1,2 & 100,0 & 1,8\end{array}$

Samat, $\%$

Läänin maaseu-

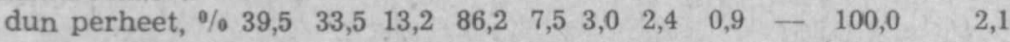

Tämän asetelman numeroista kuvastuu selvästi s u u r ten perheiden asuntojen ahtaus. Perhelisäperheistä oli suhteellisesti suuremmalla osalla kuin läänin maaseudun kaikis- 
ta perheistä vain 1 huoneen asuntoja, jotka samalla olivat keittiönä, ja sama oli asian laita 2 huoneenkin (huoneen ja keittiön) asuntoihin nähden, niin että pienasuntoa suurempi asunto oli läänin perhelisäperheistä vain $4,7 \%$ :lla, kun vastaava luku läänin maaseudun kaikkiin perheisiin nähden oli 13,8\%. Tutkituista perheistä asui $84,5 \%$ vain yhden tai kahden huoneen huoneistossa, mutta läänin maaseudun kaikista perheistä ainoastaan $73,0 \%$. Kun perhelisäperheiden hallussa oli keskimäärin vain 1,8 huonetta asuntoa kohden, oli vastaava luku läänin maaseudulla 2,1. Vaikka perhelisäperheet ovat suurimpia, on siis niiden keskuudessa vain $1 / 7: 1 l a(14,3 \%)$ huonelukunsa puolesta perheasunnoksi sopiva asunto (ainakin 2 huonetta ja keittiö).

Tarkasteltaessa tutkittuja asuntoja huoneluvun ja h allintamuodon suhteen havaitaan myös perhelisäperheisiin nähden pitävän paikkansa maaseudun asuntotutkimuksessa todetun säännöllisyyden, että omistajan asuntojen ryhmässä asuntokanta on huomattavasti korkeampi kuin vuokraasuntojen $^{28}$, sillä Kuopion läänin perhelisäperheistä, joilla oii oma asunto, oli yli $2 / 3$ :lla $(64,5 \%) 2$ tai useamman huoneen asunto, kun sensijaan vuokralla asuvista oli suhteellisesti vielä suuremmalla osalla $(70,0 \%)$ vain 1 huoneen asunto.

Sellaisia asuntoja, joissa oli myös ilman lämmityslaitteita olevia huoneita (etupäässä ullakkokamareita), oli tutkittujen perhelisäperheiden asunnoista $11,9, \%$ vastaavan maaseudun asuntotutkimuksesta saadun luvun ollessa $11,3 \%$. Vain neljässä tapauksessa 51 :stä oli 2 huonetta vailla lämmityslaitteita.

Edellä on tarkasteltu ainoastaan huonelukua, mutta tämän ohella on otettava huomioon myös huoneiston pinta-ala. Hankittaessa tietoja tästä on mukaan otettu vain asuntojen ns. nettopinta-ala ja jätetty mittauksesta pois eteiset ja komerot. Nämä ovatkin maaseudulla yleensä kylmät. Asuntojen pinta-aloja koskevat tutkimuksen tulokset rajoitettuina ainoastaan pienasuntoihin, joihin nähden pinta-alalla on suurempi merkitys, sisältyvät seuraavaan taulukkoon. 


\begin{tabular}{|c|c|c|c|c|c|c|c|c|c|c|c|c|c|c|c|c|c|}
\hline \multirow{3}{*}{ 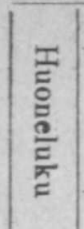 } & \multicolumn{15}{|c|}{ Asuntoja joiden pinta-ala oli, $\mathrm{m}^{2}$} & \multirow{3}{*}{ 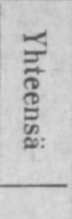 } & \multirow{3}{*}{ 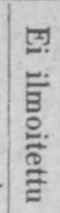 } \\
\hline & $\frac{1}{0}$ & $\frac{\vec{v}}{\overrightarrow{1}}$ & $\begin{array}{l}\vec{a} \\
i \\
\mathbb{5}\end{array}$ & $\underset{\sim}{\sim}$ & $\underset{\text { ja }}{\tilde{i}}$ & $\underset{w}{\omega}$ & $\begin{array}{l}\omega \\
1 \\
0\end{array}$ & $\begin{array}{l}\vec{t} \\
\vec{\omega}\end{array}$ & के & $\begin{array}{l}\simeq \\
8\end{array}$ & $\frac{a}{1}$ & $\begin{array}{l}7 \\
1 \\
8\end{array}$ & $\begin{array}{l}\infty \\
1 \\
8\end{array}$ & $\frac{1}{1}$ & $\frac{\overrightarrow{0}}{1}$ & & \\
\hline & \multicolumn{15}{|c|}{$\%$} & & \\
\hline \multirow[t]{2}{*}{$\begin{array}{c}1 \\
2 \\
3 \\
1-3\end{array}$} & $\frac{5,0}{\frac{5}{2,4}}$ & $\frac{9,9}{\overline{4,7}}$ & $\begin{array}{r}17,7 \\
4,2 \\
2,6 \\
10,4\end{array}$ & $\begin{array}{r}26,5 \\
8,4 \\
\frac{16,1}{16} \\
\end{array}$ & $\begin{array}{r}16,0 \\
15,0 \\
\overline{14,0}\end{array}$ & $\begin{array}{r}9,4 \\
16,3 \\
2,6 \\
11,7\end{array}$ & $\begin{array}{r}7,2 \\
18,1 \\
2,6 \\
11,4\end{array}$ & \begin{tabular}{|r|}
1,1 \\
11,5 \\
5,3 \\
6,0
\end{tabular} & $\begin{array}{r}3,3 \\
11,5 \\
10,5 \\
7,5\end{array}$ & $\begin{array}{r}1,6 \\
10,2 \\
18,4 \\
7,0\end{array}$ & $\begin{array}{r}0,6 \\
3,0 \\
29,0 \\
4,4\end{array}$ & $\begin{array}{r}\overline{1,2} \\
13,2 \\
1,8\end{array}$ & $\left|\begin{array}{c}1,1 \\
7,9 \\
1,3\end{array}\right|$ & $\begin{array}{l}0,6 \\
0,6 \\
2,6 \\
0,8\end{array}$ & & $\begin{array}{l}100,0 \\
100,0 \\
100,0 \\
100,0\end{array}$ & \\
\hline & \multicolumn{17}{|c|}{ Lukumäärä } \\
\hline-3 & 9 & 18 & 40 & 62 & 54 & 45 & 44 & 23 & 29 & 27 & 17 & 7 & 5 & 3 & 2 & 385 & 17 \\
\hline
\end{tabular}

Yhden huoneen asunnoista oli siis eniten ryhmään $21-25$ $\mathrm{m}^{2}$ kuuluvia (maaseudun asuntotutkimuksessa vuonna 193716 $20 \mathrm{~m}^{2}$ ), 2 huoneen huoneistoista $36-40 \mathrm{~m}^{2}$ (samoin maaseudun asuntotutkimuksessa ). Kaikkien tutkittujen asuntojen keskimääräinen pinta-ala oli $38 \mathrm{~m}^{2}$. Miten perhelisäperheiden keskuudessa 1 huoneen asunnot olivat pinta-alaltaan hiukan suurempia, mutta 2 ja 3 huoneen asunnot pienempiä kuin yhtä monta huonetta käsittävät asunnot yleensä läänin maaseudulla, käy selville seuraavasta yhdistelmästä, josta näkyy tutkittujen asuntojen keskimääräinen pinta-ala eri asuntotyypeissä.

$\begin{array}{ccc}\begin{array}{c}\text { Keskimääräinen pinta-ala } \\ \left(\mathrm{m}^{2}\right)\end{array} & \begin{array}{c}\text { asunnoissa, joissa } \\ \text { huoneita oli }\end{array} \\ 1 & 2 & 3 \\ 1 & 37,2 & 56,5 \\ 25,1 & 39,6 & 65,3\end{array}$

$\begin{array}{lllll}\text { Tutkitut perhelisäperheet } \ldots \ldots \ldots \ldots \ldots \ldots & 25,1 & 37,2 & 56,5 \\ \text { Läänin maaseudun perheet } \ldots \ldots \ldots \ldots \ldots . & 21,7 & 39,6 & 65,3\end{array}$

Vuonna 1937 asunnot Kuopion läänin maaseudulla siis yleensä olivat pienemmät kuin nyt tutkittujen perheiden asunnot, mutta jälkimmäisethän eivät olleetkaan yksinäisten henkilöjen eivätkä pienten perheidenkään hallussa.

\section{Asumistiheys.}

Ryhdyttäessä sitten käsittelemään asuntojen huoneluvun ja niissä asuvien asukkaiden luvun keskinäistä riippuvaisuutta 
esitetään ensin seuraava asetelma valaisemaan sitä, s u u ri k o os a a k kaista asui huoneluvultaan erilaisissa asunoissa.

Asukkaita asunnoissa, joiden huoneluku oli

Tutkitut perhelisäperheet,

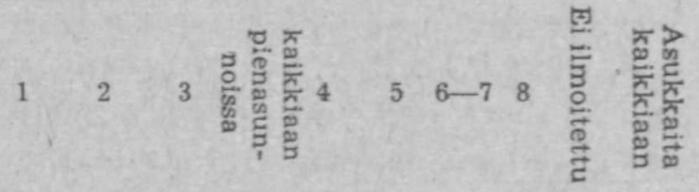

luku

Samat, \% kaikista

asukkaista

Läänin maaseudun perheet,

$\begin{array}{llllllll}1224 & 1645 & 502 & 3371 & 200 & 23 & - & -463640\end{array}$

$\begin{array}{llllll}33,6 & 45,2 & 13,8 & 92,6 & 5,5 & 0,6\end{array}-1,3100,0$

Kuten edellä (s. 167) on todettu, oli perhelisäperheiden keskuudessa suhteellisesti enemmän 1 ja 2 huoneen asuntoja kuin läänin asunnonhaltijain keskuudessa yleensä. Kun lisäksi otetaan huomioon, että perhelisäperheet olivat yleensä suurempia kuin muut, on luonnollista, että suhteellisesti suurempi osa perhelisäperheiden jäsenistä asui pienissä asunnoissa kuin muiden perheiden. Tämän asiain tilan vahvistavat edellisen yhdistelmän luvut selvästi. Kun läänin maaseudulla $65,1 \%$, siis noin $2 / 3$, asukkaista asui 1 tai 2 huoneen asunnoissa, oli vastaava suhdeluku tutkituissa perheissä $78,8 \%$ eli n. 4/5. Kun asunnoissa, joita ei voida lukea pienasunnoiksi, asui läänin maaseudulla $19,1 \%$ kaikista asukkaista eli n. $1 / 5$, oli vastaava luku tutkittuihin perheisiin nähden vain $6,1 \%$.

Millainen tilanne oli as umisryhmien (perheiden) suuruuteen nähden (vrt. s. 151), käy ilmi seuraavasta asetelmasta.

Tutkitut perhelisäper-

heet, luku

Samat, \%

Läänin maaseudun perheet, $\%$
Asunnoista oli sellaisia, joissa oli asukkaita Yh-

$\begin{array}{lllllllll}-4 & 4 & 5 & 6 & 7 & 8 & 9 & 10 & 11 \text { - teensä }\end{array}$

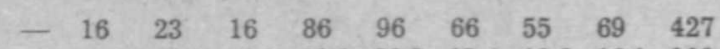

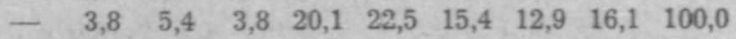

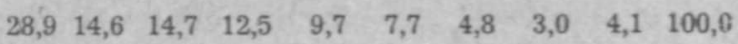


Kun läänin maaseudulla yli $2 / 3(70,7 \%)$ asunnoista oli sellaisia, joissa asui 6 henkilöä tai vähemmän, oli tutkituista asunnoista $87,0 \%$ sellaisia, joissa asui 7 henkilöä tai enemmän. Ja kuitenkin oli, kuten edellä jo huomautettiin, tutkituilla perheillä suhteellisesti enemmän pieniä 1 ja 2 húoneen asuntoja kuin läänin maaseudun perheillä yleensä.

Koska köyhimmät perheet eivät voi hankkia asuntoa, jossa on monta huonetta, vaikka niihin kuuluisi useitakin henkilöitä, on luonnollista, että a sukkaiden keskiluku asuntoa koh den ei nouse samassa suhteessa, kuin huoneluku suurenee. Miten tämä maaseudun asuntotutkimuksessa ilmennyt seikka pitää paikkansa nyt tutkittuihin perheisiinkin nähden, käy ilmi seuraavasta yhdistelmästä.

\begin{tabular}{|c|c|c|c|c|c|c|c|c|}
\hline & & $\begin{array}{l}\text { kkai } \\
\text { nois }\end{array}$ & $\begin{array}{l}\text { a } 100 \\
a, \text { joi }\end{array}$ & $\begin{array}{l}\text { asun } \\
\text { len } r\end{array}$ & $\begin{array}{l}\text { a ko } \\
\text { lonel }\end{array}$ & $\begin{array}{l}\text { den } \\
\text { ku o }\end{array}$ & un- & 点 \\
\hline & 1 & 2 & 3 & 4 & 5 & $6-7$ & 8 & \\
\hline isäperheet .. & 805 & 844 & 930 & 1053 & 1150 & - & - & 85 \\
\hline Läänin maaseudun perheet & 433 & 512 & 628 & 669 & 755 & 827 & 891 & \\
\hline
\end{tabular}

Tutkituissa asunnoissa asui siis, mikäli on kysymys 1 huoneen asunnoista, lähes kaksi kertaa niin suuri määrä asukkaita asuntoa kohden kuin läänin maaseudulla yleensä. Tämä suhde pienenee kuitenkin sitä mukaa kuin siirrytään useamman huoneen asuntoihin. Asetelmasta on myöskin nähtävissä se mielenkiintoinen seikka, että vielä 5 huoneen asunnoissa Kuopion läänin maaseudulla asui keskimäärin vähemmän ihmisiä kuin perhelisäperheiden 1 huoneen asunnoissa. Asukkaiden lukumäärä asuntoa kohden olikin tutkittujen perhelisäperheiden keskuudessa 8,5 ja läänin maaseudulla yleensä 5,3.

Suurempaa mielenkiintoa kuin asukkaiden keskiluku asuntoa kohden herättääkin a s ukkaiden keskiluku hu onet ta koh den, jolla tavallisesti ilmaistaan a sum is tiheyden aste. Asukkaiden määrästä huonetta kohdenhan suuresti riippuu perheen viihtyisyys sekä kodin siisteys ja hygieeninen ja joskus siveellinenkin taso. Seuraava asetelma sisältää tietoja asumistiheydestä eri suuruisissa asunnoissa. 
Asukkaita 100 asuinhuonetta kohden asunnoissa, joiden huoneluku oli

$\begin{array}{llllllll}1 & 2 & 3 & 4 & 5 & 6-7 & 8\end{array}$

Tutkitut perhelisäperheet Läänin maaseudun perheet . $\begin{array}{ll}805 & 422\end{array}$

433256

310263

$209 \quad 167$

\section{0}

151

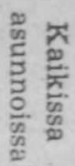

455

246

Asumistiheys oli siis, kun kaikki asunnot otetaan huomioon, Kuopion läänin perhelisäperheiden keskuudessa ( 4,6 henkeä huonetta kohden) noin $9 / 5$ läänin maaseudulla yleensä vallinneesta (2,5 henkeä huonetta kohden) eli lähes 2 kertaa niin suuri kuin jälkimmäinen. Tällainen erotus elintasossa, sikäli kuin se ilmenee asumistiheytenä, vähenee, sitä mukaa kuin siirrytään suurempiin asuntoihin, sillä kun 1 huoneen asunnossa asuvien perhelisäperheiden asumistiheys oli $85,9 \%$ yleensä vallinnutta suurempi, oli vastaava luku 5 huoneen asunnoissa majaileviin perheisiin nähden $52,3 \%$. Vielä 4 huoneen asunnoissa asuvien perhelisäperheiden asumistiheys oli suurempi kuin yleensä 2 huoneen asunnoissa asuvien perheiden. . 1 h u o n e en a su n no iss a perhelisäperheissä, jollaisia kaikista tällaisten perheiden asunnoista oli $43,1 \%$ (vrt. s. 167), olikin a s u m is t iheys sietämättömän suuri, keskimäärin 8 henkeä huonetta kohden, ja kuitenkin, kuten edellä (s. 169) on todettu, oli tällaisen huoneen pinta-ala keskimäärin vain $25,1 \mathrm{~m}^{2}$. Nilsiässä asui èäässä 1 huoneen asunnossa 14 henkeä.

Näiden moninaisten tarkastelujen jälkeen herää ehkä kysymys, suurtako osaa tutkituista asunnoista sitten voidaan pitää a ht a a sti a suttuin a ja kuinka suri osa tutkittuihin perheisiin kuuluvista henkilöistä asui tällaisissa asunnoissa. Tätä kysymystä valaistaessa on ensin sovittava siitä, miten käsite »ahtaasti asuttu asunto» on määriteltävä. Kuten maaseudun asuntotutkimusta selostavassa julkaisussa on mainittu, on ulkomailla toimeenpannuissa asuntotutkimuksissa tavallisesti asunto, jossa asuu 2 tai useampia henkilöitä huonetta kohden, katsottu ahtaasti asutuksi, mutta meillä on tyydytty siihen, että ainoastaan asunnot, joissa asuu vähintään 3 henkilöä huonetta 
kohden, on luettu tähän ryhmään. ${ }^{29}$ Tällaisen terminologian pohjalla saadaan liika-asuttujen asuntojen ja niiden asukkaiden osuudeksi kaikista asunnoista ja koko asukasluvusta seuraava yhdistelmä.

Ahtaasti asut- Asukkaita Huoneluku Kaikkiaan tuja asuntoja niissä tuntematon

Luku $\%$ Luku $\%$ Luku \% asun- asuktoja kaita

$\begin{array}{lllllllll}\text { Tutkitut perhelisäperheet } & 371 & 86,9 & 3252 & 89,3 & 5 & 1,2 & 427 & 3640\end{array}$ Läänin maaseudun perheet $1834 \quad 45,6 \quad 11491 \quad 54,3 \quad-\quad-\quad 4021 \quad 21159$

Tämä asetelma osoittaa, että ahtaasti asuminen perhelisäperheiden keskuudessa oli lähes kaksi kertaa niin tavallista kuin maaseudun perheiden keskuudessa yleensä ja että perhelisäperheiden jäsenistä oli vain 1/10 sellaisia, jotka eivät asuneet ahtaasti. Termi »ahtaasti asuminen» on kuitenkin ylimalkainen, ja sen piiriin voi kuulua hyvinkin erilaisia tapauksia. Seuraava taulukko selvittää ahtaasti asumisen eri asteita.

\begin{tabular}{|c|c|c|c|c|c|c|c|c|}
\hline & \multicolumn{4}{|c|}{$\begin{array}{c}\text { Ahtaasti asuttuja asuntoja } \\
\text { \%o:ina kaikista asunnoista, } \\
\text { kun }\end{array}$} & \multicolumn{4}{|c|}{$\begin{array}{l}\text { Ahtaasti asuttujen asunto- } \\
\text { jen asukkaat \%o:ina kai- } \\
\text { kista asukkaista, kun }\end{array}$} \\
\hline & \multicolumn{8}{|c|}{ asukkaita huonetta kohden oli } \\
\hline & $3,0-3,9$ & $4,0-5,9$ & $6,0-$ & $3,0-$ & $3,0-3,9$ & $4,0-5,9$ & 6,0 & 3,0 \\
\hline \multirow{2}{*}{$\begin{array}{l}\text { Tutkitut perheli- } \\
\text { säperheet ...... } \\
\text { Läänin maaseu- } \\
\text { dun perheet } . .\end{array}$} & 204 & 32,3 & 34,2 & 86 & 20,4 & 32,9 & 36,0 & 89,3 \\
\hline & 17,0 & 17,2 & 11,4 & 45,6 & 18,1 & 19,5 & 16,7 & 54,3 \\
\hline
\end{tabular}

Tämä taulukko antaa lohduttoman kuvan asunto-olosuhteista, mitkä niin suuressa määrässä vallitsevat maaseudun suurten perheiden keskuudessa, sillä asuihan joka kolmas tutkittujen perheiden jäsenistä asunnossa, jossa majaili vähintään 6 henkeä huonetta kohden, kun sensijaan läänin maaseudulla yleensä »vain» joka kuudes ihminen oli vastaavassa asemassa. Yli 2/3 perhelisäperheisiin kuuluvista henkilöistä asui asunnoissa, joiden asukasluku huonetta kohden oli 4 tai sitä suurempi. 
Kuten edellä on esitetty ja kuten maaseudun asuntotutkimuksestakin kävi ilmi, suuret perheet asuivat yleensä paljon ahtaammin kuin muu osa väestöä. Seuraava taulukko näyttää tämänkin tutkimuksen tuloksena, että p i en e m m is sä a sunnoissa yleensä asui en e m män lapsia kuin su uremmissa.

\begin{tabular}{|c|c|c|c|c|c|c|c|c|c|c|c|c|}
\hline & \multicolumn{10}{|c|}{ Asukkaista oli asunnoissa, joissa oli } & \multirow{2}{*}{\multicolumn{2}{|c|}{$\begin{array}{l}\text { Kaikista } \\
\text { asukkais- } \\
\text { ta oli }\end{array}$}} \\
\hline & \multicolumn{2}{|c|}{1 huone } & \multicolumn{2}{|c|}{2 hoonetta } & \multicolumn{2}{|c|}{$\mid 5$ huonetta } & \multicolumn{2}{|c|}{$\left|\begin{array}{c|}\text { yli } 3 \text { huo- } \\
\text { netta }\end{array}\right|$} & \multicolumn{2}{|c|}{$\begin{array}{l}\text { huoneluku } \\
\text { tuntematon }\end{array}$} & & \\
\hline & 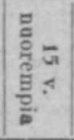 & 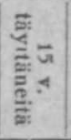 & 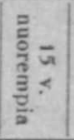 & 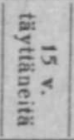 & 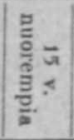 & 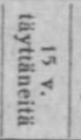 & 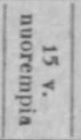 & 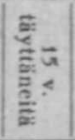 & 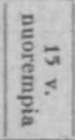 & 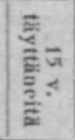 & 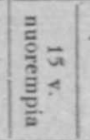 & 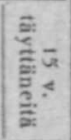 \\
\hline $\begin{array}{l}\text { Tutkitut perhe- } \\
\text { lisäperheet, lu- } \\
\text { ku ... ...... } \\
\text { Samat, \% .... } \\
\text { Läänin maa- } \\
\text { seudun per- } \\
\text { heet, } \% \text {. . . . }\end{array}$ & $\begin{array}{l}753 \\
61,5\end{array}$ & $\begin{array}{l}471 \\
38,5\end{array}$ & $\begin{array}{r}1014 \\
61,6\end{array}$ & $\begin{array}{l}631 \\
38,4\end{array}$ & $\begin{array}{l}285 \\
56,8\end{array}$ & $\begin{array}{l}217 \\
43,2\end{array}$ & $\begin{array}{l}115 \\
51,6\end{array}$ & 108 & $\begin{array}{l}25 \\
54,3\end{array}$ & $\begin{array}{c}21 \\
45,7\end{array}$ & $\begin{array}{l}2192 \\
60,2\end{array}$ & $\begin{array}{l}1448 \\
39,8\end{array}$ \\
\hline
\end{tabular}

Edellä esitetyt maaseudun asuntotutkimuksesta poimitut luvut osoittavat, että etenkin sellaiset asunnot, jotka huonoimmin soveltuivat perheasunnoiksi, olivat lasten kansoittamia ja että heitä oli șuhteellisesti sitä vähemmän, mitä suurempi huoneisto oli kysymyksessä. Perhelisäperheisiin nähden piti sama sääntö paikkansa ainoastaan sillä erotuksella, että 2 huoneen asunnoissa oli suhteellisesti vähän enemmän lapsia kuin 1 huoneen, ja tämä onkin luonnollista, kun on kysymys suurista perheistä, sillä kovin suuren perheen on paljon vaikeampaa tulla toimeen 1 kuin 2 huoneen asunnossa, mutta viimeksimainitunlaisessa asunnossa voi suurikin perhe helpommin asua. Kun 1 huoneen asunnoissa asuvien perhelisäperheiden jäsenistä $3 / 5$ oli lapsia ja vain $2 / 5$ aikuisia, oli suhde tasan päinvastainen yleensä Kuopion läänin maaseudulla. Sama seikka ilmenee myös seuraavista luvuista, jotka osoittavat, suuriko osa toisaalta lapsista ja toisaalta aikuisista asui eri asuntotyypeissä. 


\section{Lapsia ja aikuisia \% näiden ryhmien koko määrästä asunnoissa, joissa oli}

Tutkitut perhelisäperheet

Läänin maaseudun perheet
15 v. nuorempia 33,6

15 v. täyttäneitä 32,5

15 v. nuorempia 37,3

15 v. täyttäneitä 30,1
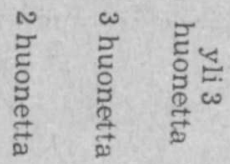

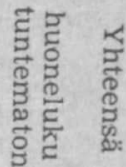

$\begin{array}{ll}45,2 & 13,8\end{array}$

6,1

43,6

34,2

31,8
15,0

15,0

16,1

\section{7,5}

13,5

$-100,0$

1 ja 2 huoneen asunnoissa asui siis suurempi osa lapsista kuin aikuisista, kun taas aikuiset olivat suuremmassa määrässä ryhmittyneet 3 huoneen tai sitä suurempiin asuntoihin. Että erotus tässä suhteessa maaseudulla yleensä oli suurempi kuin perhelisäperheissä, on luonnollista, kun ottaa huomioon, että perhelisäperheet käsittivät suhteellisen homogeenisen ryhmän maaseudun väestön yleensä taas muodostaessa suuruudeltaan paljon enemmän toisistaan eroavia asumisryhmiä.

\section{Asukkaat talouskunta-asemansa mukaan.}

Kysymystä, missä määrin asunnoissa perheen jäs en t e n lis ä ks i asui muitakin, valaisevat seuraavat asetelmat.

Tutkitut perhelisäperheet, luku Samat, $\%$.................. Läänin maaseudun perheet, \%

Tutkitut perhelisäperheet, luku Samat, $\%$.................... Läänin maaseudun perheet, $\%$
Asuntoja, joissa asui

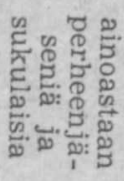

391

91,6

73,2

Koko asukasmäärästä oli

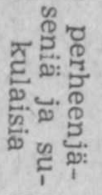

3564

97,9

89,5

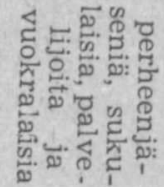

15

3,5

17,3

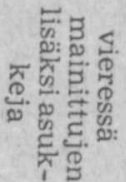

21

4,9

9,5
427

100,0

100,0
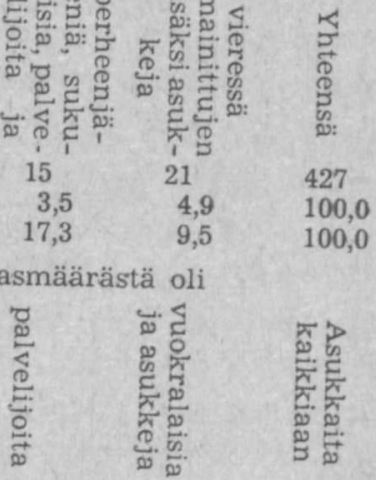

21

0,6

6,3

55

1,5

4,2

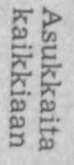

3640

100,0

100,0 
Perhelisäperheiden yhteydessä ei siis perheenjäsenten ja sukulaisten lisäksi asunut asukkeja eikä muita vuokralaisia läheskään niin suuressa määrässä, kuin maaseudulla yleensä oli laita, ja myös palvelijoiden määrä oli tutkittujen perheiden keskuudessa hyvin vähäinen.

\section{HAJATIETOJA TALOUDELLISISTA OLOISTA.}

Tutkimuksessa kerättiin myös tietoja perheiden harjoittaman maanviljelyksen la ajuudesta. Kun asuntoviljelmillä varsinainen maanviljelys on vain sivuelinkeinona, on seuraavassa otettu huomioon ainoastaan kokonaispinta-alaltaan kahta ja peltopinta-alaltaan yhtä hehtaaria suuremmat viljelmät. Edelliseen ryhmään kuului tutkituissa Kuopion läänin kunnissa 279:n $(65,3 \%)$ ja jälkimmäiseen $226(52,9 \%)$ perheen tilat. Kun ammattimerkinnän mukaan tilallisiin ja pienviljelijöihin on samoissa kunnissa luettu vain 209 perheen päähenkilöt $(49,0 \%)$ (ks. S. 156), on siis näin huomioon otetuistakin viljelmistä vielä osa sellaisia, joilla maanviljelystä ei ole pidetty pääelinkeinona. Kuten perhelisälain edellyttämän tulorajan huomioon ottaen on luonnollista, oli perhelisäperheillä hallussaan vain etupäässä pieniä viljelmiä (ks. ed. s. 157). Tämä käy ilmi seuraavista yhdistelmistä, joissa tutkittujen perheiden viljelmien pinta-aloja on verrattu ko. kuntien kaikkien viljelmien aloihin, sellaisina kuin viimeksi mainitut esiintyivät vuonna 1941 suoritetussa yleisessä maatalouslaskennassa. ${ }^{30}$

Kokonaispinta-alaltaan 2 ha suuremmista viljelmistä oli ha-määrältään alla mainitun suuruisia

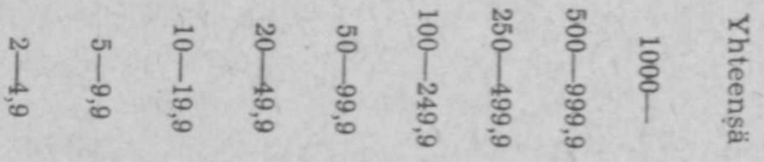

Tutkitut perhelisäperheet, luku ..

Samat, $\%$ k...... $\begin{array}{llllllllll}56 & 26 & 56 & 105 & 24 & 11 & 1 & - & -279\end{array}$ $\begin{array}{llllllllll}20,1 & 9,3 & 20,1 & 37,6 & 8,6 & 3,9 & 0,4 & - & - & 100,0\end{array}$ kaikki viljelmät, $\%$....... $\begin{array}{llllllllll}8,7 & 7,0 & 16,3 & 35,5 & 15,6 & 12,7 & 2,6 & 1,1 & 0,5 & 100,9\end{array}$ 
Kokonaispeltoalaltaan 1 ha suuremmista viljelmistä oli peltoalaltaan (ha) alla maini.un suuruisia

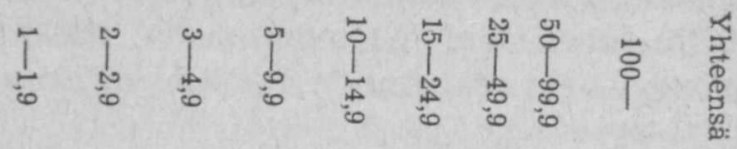

Tutkitut perhelisä-

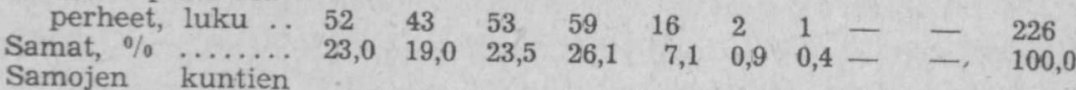

kaikki viljel-

mät, $\%$........

$$
\begin{array}{llllllllll}
15,7 & 13,7 & 20,2 & 28,6 & 11,6 & 6,8 & 3,2 & 0,2 & (0,04) & 100,0
\end{array}
$$

Kokonaispeltoalaltaan 1 ha suurempien viljelmien peltoalasta kuului peltoalaltaan (ha) alla mainitun suuruisille viljelmille

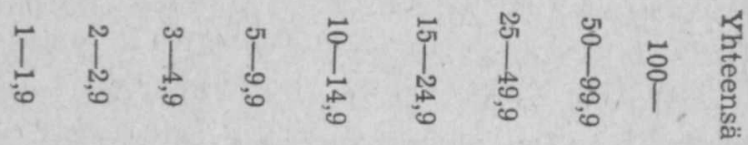

Tutkitut perhelisä-

perheet, ha $. .67,9 \quad 97,2 \quad 198,2 \quad 399,1 \quad 185,8 \quad 38,5 \quad 30,0 \quad-\quad-1016,7$

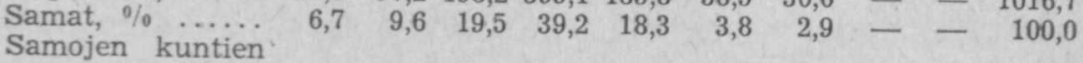

kaikki viljel-

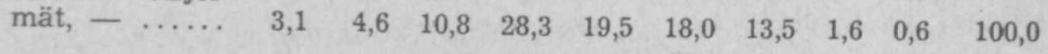

Kun tutkittujen Kuopion läänin kuntien kaikkien 2 ìehtaaria suurempien viljelmien luvusta lähes $1 / 3(32,5 \%)$ oli kokonaispinta-alaltaan vähintään 50 hehtaarin suuruisia, oli vastaava luku perhelisäperheiden osalta vain $12,9 \%$. Peltopinta-alaltaan 5 hehtaaria pienempiä viljelmiä oli kaikistakin viljelmistä lähes puolet $(49,6 \%)$, mutta perhelisäperheiden viljelmistä kokonaista $2 / 3(65,5 \%)$. Vähintään 10 hehtaarin suuruinen pinta-ala oli viimeksi mainituista vain $8,4 \%$ :lla vastaavan luvun kaikkiin viljelmiin nähden ollessa $21,8 \%$. Kun kaikkien tilojen kysymyksessä ollen peltoalasta kuului $33,7 \%$ sellaisille viljelmille, joilla oli peltoa vähintään 15 hehtaaria, oli vastaava luku perhelisäperheiden viljelmiin nähden vain $6,7 \%$.

Tutkimuksessa koottiin tietoja myös perheiden hallussa olleista maataloustyökoneista. Niittokoneita oli vain 
72 viljelmällä, joten peltopinta-alaltaan 5 hehtaaria pienemmät viljelmät jäivät niistä yleensä osattomiksi. 41 eli lähes puolta vähemmän kuin viimeksi mainittuja koneita oli hevosharavia ja sitäkin vähemmän, 34, puimakoneita. Vuoden 1941 maatalouslaskenta antoi mainittujen kuntien kaikkien viljelmien osalta samantapaisia tuloksia. ${ }^{31}$

$\mathrm{Pu}$ tarhanhoit oa jossakin muodossa ilmoittivat tietojenkerääjät harjoitettavan 298 perheessä, mikä vastaa $70,8 \%$ kaikista tutkituista perheistä.

Jos kotieläinten lukumäärää verrataan peltopintaalaltaan yhtä hehtaaria suurempien viljelmien lukumäärään, oli tutkituissa perheissä hevosia keskimäärin 1,1 (vuoden 1941 maatalouslaskennan mukaan ko. kunnissa olevien hevosten luku verrattuna vastaavan suuruisten viljelmien lukumäärään oli keskimäärin $\left.1,4^{32}\right)$, nautaeläimiä $6,4(7,1)$, lampaita $5,2(2,0)$, sikoja $1,1(1,4)$ sekä kanoja ja kukkoja 2,6 $(3,0)$. Onkin luonnollista, että kotieläinten keskimäärä oli viljelmillä yleensä suurempi kuin perhelisäperheiden viljelmillä, sillä edellisten keskuudessahan on suurempia viljelmiä kuin jälkimmäisten. Lampaiden hoito oli kuitenkin perhelisäperheiden keskuudessa tavallista yleisempää. Lampaita samoin kuin lehmiäkin oli myös pelkiksi asuntoviljelmiksi katsottavilla viljelmillä.

Kun $\mathrm{n}$ avetat luokiteltiin niiden $\mathrm{kunnon} m \mathrm{mka}$, oli hyviksi katsottavia $15,1 \%$, keskinkertaisia $29,5 \%$, huonoja $52,7 \%$ ja kelvottomia $2,7 \%$.

Noin puolet tutkituista perheistä olivat sellaisia, joissa $\mathrm{k} a-$ la s tu s t a ei lainkaan harjoitettu toisen puolen ollessa sellaisia, joissa kalastettiin vähän (kotitarpeiksi) neljää Tuusniemen ja Muuruveden perhettä lukuunottamatta, joilta kalaa liikeni myytäväksikin.

Palkatun a putyövoiman käytöstä saatiin tietoja vain Nilsiästä ja Vieremältä. Vain noin joka neljännessä $(24,4 \%)$ näiden kuntien tutkituista perheistä käytettiin palkattua aputyövoimaa, mutta vain noin joka 20 :nnessä perheessä $(5,5 \%)$ palkatun aputyövoiman käyttö oli jatkuvaa. 
Kyselylomakkeessa oli varattu tilaa myös perhelisän saajain toivomuksille. Näiden valossa ylivoimaisesti kaikkein kipeimmiksi tunnettiin perheenjäsenten (etenkin lasten) vaatetusta koskevat puutteellisuudet (250 toivomusta), ja sen jälkeen seurasivat puutteelliset asunto-olot (57), jalkineet (41), huonekalut (38) ja makuuvaatteet (34). 'Lasten vaatetuksen puutteellisuutta todistaa myös se, että perhelis ien 1 u ontoissuoritusmuodoista tutkituissa perheissä vuosina 1943-1945 ensi sijalla olivat juuri lastenvaatetoimitukset. Näiden jälkeen oli viljelyshuolto laajimmin käytetty perhelisäsuoritusten muoto. ${ }^{33}$ Millaisia puutteita huonekalujen suhteen saattoi esiintyä, sitä kuvaavat seuraavat tietojenkerääjän antamat esimerkit muutamasta Vieremän perhelisäperheestä. »Nukutaan lattialla, vain 2 sänkyä 8 hengellä»; »1 sänky, sekin laho, 8 hengellä»; »mökin ainoana kalustona 2 pöytää ja penkit, sänkyjä ei lainkaan»; »perheellä vain 1 sänky, vuodevaatteita ei ole (6 henkeä)».

\section{Lähdeviitteitä ja huomautuksia.}

i Nieminen, Armas, Tietoja Helsingin suurista ja keskisuurista perheistä sekä niiden oloista vuonna 1943, Väestöpolitiikkamme taustaa ja tehtäviä, julk. Väestöliitto, Porvoo ja Helsinki 1946, ss. $201-220$.

2 Maaseudun asunto-olot vuonna 1937, Suomen virallinen tilasto (SVT) XXXII, 16.

3 Suomen tilastollinen vuosikirja (STV) $1944-45$, ss, $28-29$.

4 STV $1944-45$, Ss. $28-29$. - SVT VI, 80, ss. $25-26$; 81 , ss. $25-26$; 82 , ss. 76,$78 ; 83$, ss. $25-26 ; 84$, ss. $24-25 ; 85$, ss. $18,20,76,78 ; 87$, ss. $24-25$; 91 , ss. $24-25$; 95 , ss. 18 , 70; $98: 1$, taulut, s. 55 ; $98: 2$, s. 57 ; XXXI: B, 6 , teksti, s. 17 , taulut, s. $136 ; 7$, teksti, s. 16 , taulut, s. $136 ; 8$, teksti, s. 20 , taulut, ss. 136,$306 ; 9$, s. $108 ; 10$, s. 108 . - Tilastollisen päätoimiston imeväiskuolleisuudesta ja sosiaaliministeriön sosiaalisen tutkimustoimiston huollon varassa olevista antamia tietoja.

5 Laki perhelisälain muuttamisesta 29.12. 1944 [Asetuskokoelma (AK) n:o 1046], valtioneuvoston päätös perhelisälain toimeenpanosta 30. 12. 1944 (AK n:o 1048), sosiaaliministeriön päätös kuntien kalleusryhmityksestä 14. 12. 1942 (AK n:o 990).

6 Lain mukaan on huollettavana lapsena pidettävä myös 16 vuotta täyttänyttä työkyvytöntä lasta sekä koulunkäyntiä tai opintoja jatkavaa lasta, joka on täyttänyt 16 , mutta ei 20 vuotta. Näillä poikkeustapauksilla ei kuitenkaan ole tälle tutkimukselle merkitystä, sillä huoltolautakuntien ilmoitusten mukaan suoritettiin perhelisiä Kuopion läänin maalaiskunnissa vuonna 1945 vain 68 mainitunlaisesta 16 vuotta täyttäneestä lapsesta. Sosiaaliministeriön väestöasiaintoimiston antama tieto. 
7 Sosiaaliministeriön väestöasiaintoimiston antama tieto.

8 SVT XXXII, 16, ss. 1*-3*, 6*, 46. - STV 1937, SS .11-12. - Henkikirjoihin perustuva asukasluku oli vuonna 1937 tutkituissa läänin kunnissa 22256 ja läänin kaikissa maalaiskunnissa (maaseutu-kauppalat) 331945 .

9 STV $1944-45$, s. 9.

10 Tilastollisen päätoimiston antama tieto. - STV 1942, s. $67, \mathrm{~T}$. (taulu) $41 ; 1943$, s. 63 , T. $43 ; 1944-45$, s. 63 , T. 47.

11 Vrt. SVT VI, 98: 2, T. I-II.

12 SVT XXXII, 16, ss. $87^{*}, 58$.

13 Kalastajia oli vain Tuusniemellä 1.

14 Näitä ei tutkimuksessa esiintynyt lainkaan.

15 Näitä oli vain Tuusniemellä 1 .

16 Näihin verrattavia oli vain Vieremällä 1 poliisikonstaapeli.

17 Vieremällä 1 kansakoulunopettaja.

18 Tähän ryhmään luettavat tässä tutkimuksessa esiintyvät henkilöt olivat kaikki leskivaimoja.

19 Sosiaalinen Aikakauskirja 1948, s. 174.

20 Valtioneuvoston päätös maatalouskiinteistöistä ja poronhoidosta vuonna 1943 saatujen tulojen taksoituksessa noudatettavista verotusperusteista 20. 1. 1944, ss. 18-19. Valtiovarainministeriön verotusasiainosastossa. - Valtiovarainministeriön kiertokirje verovelvollisen ja perheenjäsenten työn arvoista 18. 2. 1944. Samassa paikassa kuin ed. - Laki maalaiskuntain kunnallishallinnosta annetun asetuksen muuttamisesta 12. 3. 1943 (AK n:o 219). - Laskelmassa on viljellyn maan ja metsämaan puhtaan tuoton raha-arvoksi ha kohti otettu tutkituissa kunnissa noudatettaviksi vahvistettujen arvojen keskimäärät (637: 50 ja 89:55), asuntoeduksi $3000 \mathrm{mk}$ ja kunnallisverotuksen lapsivähennyksen arvoksi asetuksen sisältämien raja-arvojen keskimäärä, niinikään $3000:-$. Viljelysmaan on oletettu kuuluvan I vyöhykkeen II luokkaan ja metsämaan II vyöhykkeen III luokkaan.

21 SVT XXXII, 16, s. 58.

22 Pesola, Vilho A., Näkökohtia väestökysymyksestämme, Valvoja (Helsinki) 1946. s. 206.

23 Nieminen, main. kirj., ss. 209-210.

24 SVT XXXII, 16. Esitykseen sisältyvät Kuopion läänin maaseudun perheitä koskevat suhdeluvut on laskettu tämän julkaisun tilastotauluista. Koska näitä on alkuperäisessä järjestyksessään esityksessä seurattu, ei erityisiä lähdeviittauksia niihin ole pidetty tarpeellisina.

25 Tästä tilastosta on vesijohdolla varustetut asunnot jätetty pois.

26 SVT XXXII, 16, s. 16*.

27 Sama, s. $19 *$.

28 Sama, ss. $23^{*}-25^{*}$.

29 Sama, s. 39*.

30 SVT III, $38: 3$, ss. $47-48,78-81$. Maataloushallituksen maataloustilastotoimiston antamia tietoja.

31 SVT III, 38: 2 , ss. $84-87$.

32 Sama, ss. $62-63$.

33 Myös koko maassa käytettiin vuonna 1945 lastenvaatteisiin enemmän varoja kuin muihin perhelisäsuorituksiin, nim. n. $33 \%$ perhelisävarojen kokonaismäärästä. Viljelysten edistämiseen käytettiin n. $19 \%$, asuin- ja talousrakenusten kunnostamiseen $\mathrm{n}$. $15 \%$ sekä kotieläimiin ja niiden rehuun n. $9 \%$. Sosiaalinen Aikakauskirja 1948, s. 175. 